\title{
SOME OBSERVATIONS ON THE WEATHERING OF LIMESTONE IN GLACIOGENIC MATERIAL IN THE LOHJA REGION, SW-FINLAND
}

\author{
Reino Repo and Boris G. L. Winterhalter \\ Geological Survey of Finland, Otaniemi, Finland
}

\section{ABSTRACT}

Groundwaters low in $\mathrm{pH}$ due to dissolved carbon dioxide and to acids liberated by surface waters from the upper horizons of the podsol profile have caused rapid weathering of limestone erratics occurring sporadically in glaciogenic material in the Lohja region. Especially the calcitic portion of the limestone has been dissolved and partly replaced by a brownish black earthy substance consisting of hydrous oxides of iron and manganese. Dolomitic limestone has likewise been dissolved; the calcium has gone into solution, but the magnesium has been reprecipitated.

\section{General}

The mineral matter of Quaternary deposits in Finland has generally been derived from the local crystalline bedrock. In past geological ages this bedrock was deeply weathered but the more or less loose crust has been removed and destroyed by subsequent continental glaciations. Weathered bedrock has been found in Lapland in the vicinity of the last ice-divide and farther south only in a few localities.

Thus the geology of Finland is characterized by an ancient glacially smoothed crystalline bedrock discordantly overlain by young Quaternary deposits. These deposits generally consist of almost unweathered rock debris detached from the bedrock and accumulated as a result of the last major glaciation. Only the uppermost layer of such drift accumulations has been altered since glacial times due to soil forming processes.

During the past few years in the course of the field mapping of the Quaternary deposits in the Lohja region, in southwestern Finland, the authors have found brownish black, earthy lumps (Fig. 1) occurring sporadically in the freshly exposed surfaces of gravel pits and road cuts made in glaciogenic accumulations. The finding of a corroded nucleus of limestone inside one of the lumps established them as results of the weathering of limestone erratics. Accordingly the black lumps to be discussed in the present paper are considered to be the remains of crystalline limestone altered as the result of chemical weathering in post-glacial time. The weathered material is generally very soft and thus the limestone rocks could have withstood the rigors of transportation by fluvial agents from the outcrop to the place of deposition only in an unweathered state.

\section{Geological setting}

The bedrock of the Lohja region is Precambrian in age and consists according to Härme (1960), Laitala (1961), Parras (1954), Simonen (1960) and others of acid gneisses (leptites), 


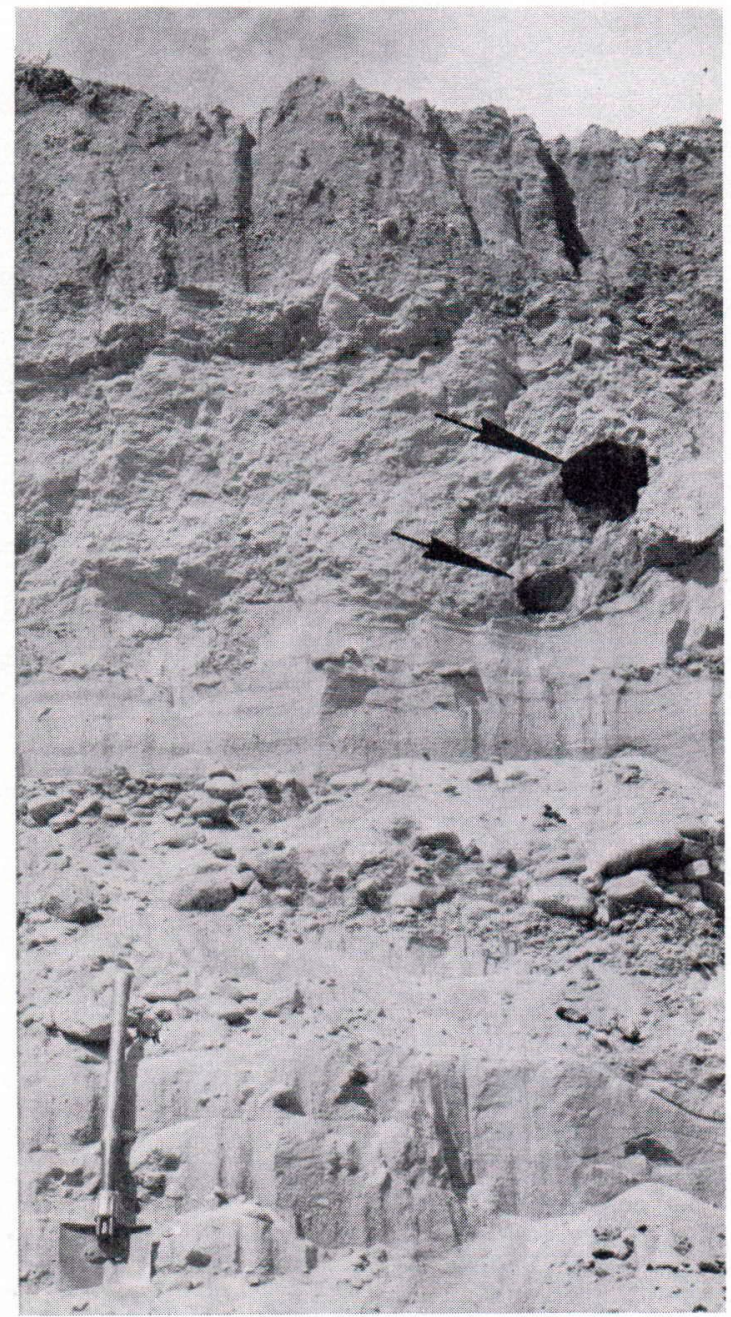

Fig. 1. Two large, black, completely weathered limestone erratics (see arrows) in glaciogenic material in the proximal part of the Salpausselkä I formation at site No. 2.

pyroxene gneisses, amphibolites, diorites and occasionally of microcline granites (Fig. 2A). In general, limestones occur sparsely in the bedrock of Finland (Eskola et.al., 1919). However, in the study area, within the town limits of Lohja, there are important occurrences of limestone at Ojamo and Tytyri being mined for calcite by the Lohjan Kalkkitehdas company. In addition, calcitic and dolomitic lenses and inclusions are fairly common in some gneisses in the area. Thus, there are enough limestone

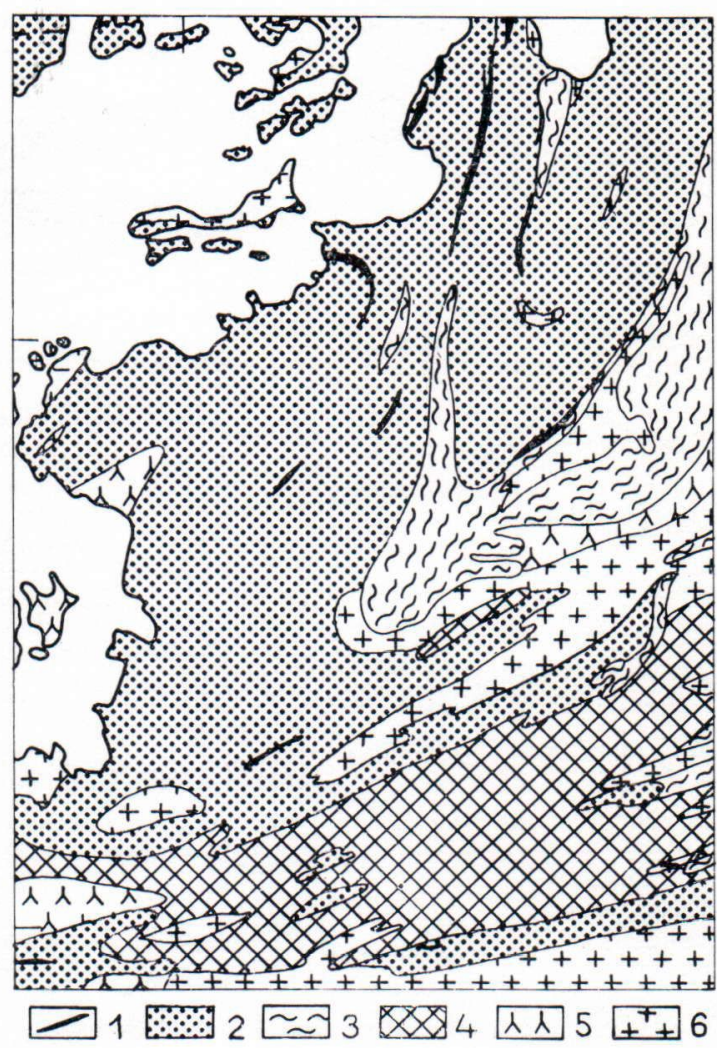

Fig. 2A. The bedrock geology of the study area compiled from Härme (1960), Laitala (1961) and Parras (1954). Legend: 1) outcrops of crystalline limestone, 2) pyroxene gneisses and leptites, 3) mica gneiss, 4) amphibolites and hornblende gneiss, 5) quartz-diorites and granodiorites, and 6) microcline granites.

outcrops to account for limestone erratics in the glaciogenic material.

The Quaternary deposits in the region consist mainly of sorted material (Fig. 2B). Various accumulation forms of coarse and fine sand and less often of gravel are most abundant. Glacial and postglacial clays are also quite common. Till as well as peat occurs, however, rather sparingly. The bedrock outcrops cover 5--10\% of the total land area. The ice-marginal formation of Salpausselkä I, running through the study area, comprises the most striking topographic feature reaching heights of 105 meters above sea level. 


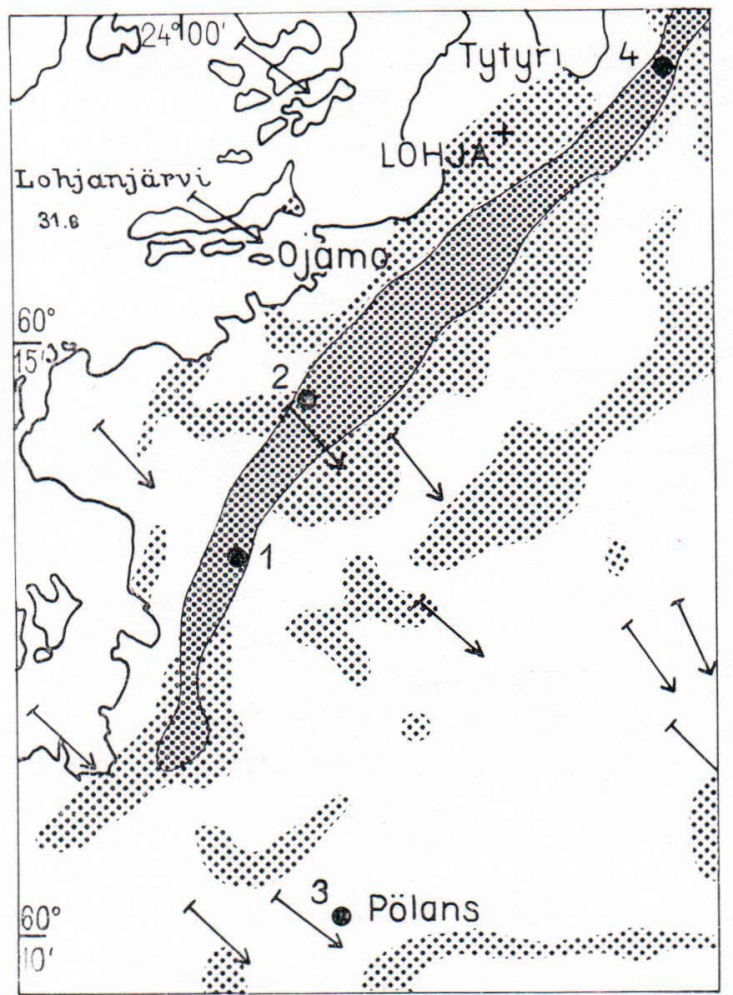

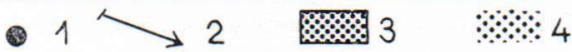

Fig. 2B. Major Quaternary deposits of the study area. Legend: 1) sampling sites of weathered limestone, 2) direction of glacial striae, 3) fluvio-glacial deposits of Salpausselkä and 4) sands.

According to the observed striae, the last glacial advance in the Lohja region was towards $\mathrm{SE}$. The ice margin retreated from the area approximately 9000 yrs B. C. (Sauramo 1923, Hyyppä 1963). The bulk of Salpausselkä I, which formed during this stage, consists of fluvioglacial deposits, although thin layers and minor lenses of till occur in places in the proximal parts. Till occurrences are however rare in the distal parts.

\section{Description of sampling sites}

Weathered limestone boulders have been found by the authors at four different sites, three of which occur in the ice-marginal formation of Salpausselkä I (Fig. 2B). Most of the samples were taken from marginal till or till-like accumulations in the proximal part of the formation. No limestone erratics were detected near or on the soil surface nor in shore deposits. Some samples were found in fluvioglacial material. It sould be added, that the sporadically occurring black lumps were not limited to any specific depth below the surface of the soil. Due to the limited number of observations no attempt is made to determine the statistical distribution of the weathered limestones according to the type of surficial deposit.

Sites No. 1 (till, SSE of Jusolampi) and No. 4 (partly washed till, SW of Lohja railroad station) both yielded only a single specimen of completely weathered limestone, with diameters of $7 \mathrm{~cm}$ and $5 \mathrm{~cm}$ respectively and from depths of $1.5 \mathrm{~m}$ and $1 \mathrm{~m}$. At site No. 3 (till, at Pölans), five completely weathered limestone pebbles ranging from 2 to $6 \mathrm{~cm}$ in diameter were found from a depth of $1-1.3$ meters. The largest number of limestone fragments were recorded from the freshly exposed vertical sides of a gravel pit dug into the proximal part of the Salpausselkä formation at site No. 2 (Fig. 3). The fragments,

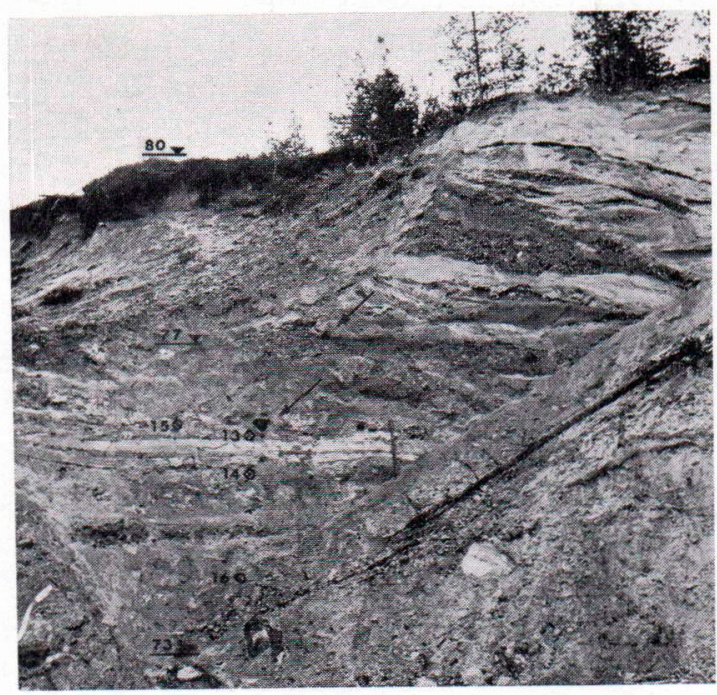

Fig. 3. A view from the same gravel pit at site No. 2 as in FIG. 1. The arrows point to weathered limestones. The numbers $13-16$ refer to the soil samples analyzed and plotted in Table 1. Also marked in the figure are the heights in meters above sea level. 
TABle 1.

Chemical analysis of weathered limestone and adjacent soil (Percentages on a dry weight basis)

\begin{tabular}{|c|c|c|c|c|c|c|c|}
\hline $\begin{array}{l}\text { Anal. } \\
\text { No. }\end{array}$ & $\mathrm{C}_{2} \mathrm{O}$ & $\mathrm{MgO}$ & $\begin{array}{l}\text { Total } \\
\mathrm{Fe}_{2} \mathrm{O}_{3}\end{array}$ & $\mathrm{MnO}$ & $\begin{array}{l}\text { Insol. }{ }^{1} \text { ) } \\
\text { in } \mathrm{Hcl}\end{array}$ & L. O. I. ${ }^{2}$ ) & \\
\hline 1 & 0.14 & 1.49 & 3.93 & 6.50 & 70.00 & $(0.00)$ & 82.06 \\
\hline 2 & 0.11 & 25.31 & 7.08 & 1.23 & 39.12 & 14.05 & 86.90 \\
\hline 3 & 9.59 & 29.90 & 7.72 & 0.95 & 33.28 & 16.13 & 97.57 \\
\hline 4 & 36.67 & 14.41 & 1.89 & 0.47 & 5.98 & 39.61 & 99.03 \\
\hline 5 & 1.84 & 24.62 & 10.29 & 11.40 & 33.68 & 15.96 & 97.79 \\
\hline 6 & 27.07 & 22.88 & 1.20 & 0.85 & 5.98 & 41.40 & 99.38 \\
\hline 7 & 34.51 & 16.73 & 0.96 & 0.72 & 9.08 & 38.26 & 100.26 \\
\hline 8 & 49.77 & 3.12 & 0.34 & 0.07 & 3.28 & 42.14 & 98.72 \\
\hline 9 & 32.96 & 18.03 & 2.14 & 0.48 & 1.10 & 45.02 & 99.73 \\
\hline 10 & 48.27 & 1.16 & 0.66 & 0.06 & 8.90 & 38.90 & 97.79 \\
\hline 11 & - & - & 0.86 & 0.06 & - & $(0.00)$ & - \\
\hline 12 & - & - & 1.04 & 0.01 & - & $(0.00)$ & - \\
\hline 13 & - & - & 1.43 & 0.02 & - & $(0.00)$ & - \\
\hline 14 & - & - & 1.42 & 0.02 & - & $(0.00)$ & - \\
\hline 15 & - & - & 1.42 & 0.02 & - & $(0.00)$ & 一 \\
\hline 16 & - & - & 1.14 & 0.01 & - & $(0.00)$ & - \\
\hline
\end{tabular}

1) Insol. in $\mathrm{HCl}=$ residue not dissolved in $10 \%$ hydrochloric acid, composed chiefly of silicates.

$\left.{ }^{2}\right)$ L.O.I. = loss on ignition, reflecting the $\mathrm{CO}_{2}$-content of sample. (0.00) denotes that no carbon dioxide was detected in sample.

1. Black substance from site No. 1.

2. Porous dark lump from site No. 3.

3. Black weathered crust of a large limestone boulder from site No, 2 .

4. Unweathered core of the above sample (Anal. 3).

5-7. Black weathered crust, transition zone and fresh core resp. of same sample from site No. 2 (Fig. 4).

8 -10. Fresh limestone chipped from large limestone boulders occurring on the bottom of the gravel pit at site No. 2 11-16. Soil samples from site No. 2 (Fig. 3)

over 20 in number, varied in size from $1-25$ centimeters in diameter. Of these only six had a diameter greater than $10 \mathrm{~cm}$, and two of the largest contained a nucleus of fairly unaltered limestone (e.g. anal. No. 7 in Table 1) inside the brownish black weathered crust).

\section{Investigation of samples}

Samples of weathered limestones taken from the different sites marked in Fig. 2 were subjected to chemical and mineralogical studies. According to mineralogical, mainly $\mathrm{X}$-ray diff-

TABLE 2.

Assay values from Table 1 recalculated on a silicate-free basis (cf. text on p. 121).

\begin{tabular}{r|c|c|c|c|c|r|r|r}
\hline $\begin{array}{c}\left.\text { Anal. }{ }^{1}\right) \\
\text { No. }\end{array}$ & $\mathrm{k}=\frac{\Sigma}{\Sigma-\mathrm{HCl}}$ & $\mathrm{k} \cdot \mathrm{CaO}$ & $\mathrm{k} \cdot \mathrm{MgO}$ & $\begin{array}{c}\left.\mathrm{k} \cdot \mathrm{CO}_{2}{ }^{2}\right) \\
\left(\mathrm{CaCO}_{3}\right)\end{array}$ & $\begin{array}{c}\left.\mathrm{k} \cdot \mathrm{CO}_{2}{ }^{2}\right) \\
\left(\mathrm{MgCO}_{3}\right)\end{array}$ & $\begin{array}{r}\mathrm{CO}_{2}{ }_{\left(\mathrm{CaCO}_{3}+\mathrm{MgCO}_{3}\right)} \\
\mathrm{k} \cdot \mathrm{LOl}\end{array}$ & $\begin{array}{c}\left.\mathrm{CO}_{2}{ }^{3}\right) \\
\mathrm{def} .\end{array}$ \\
\hline 1 & 6.81 & 0.95 & 10.14 & 0.75 & 11.1 & 11.9 & 0.00 & 11.9 \\
2 & 1.82 & 0.20 & 46.1 & 0.16 & 50.4 & 50.6 & 25.6 & 25.0 \\
3 & 1.52 & 14.6 & 45.5 & 11.5 & 49.6 & 61.1 & 24.5 & 36.6 \\
4 & 1.06 & 39.0 & 15.3 & 30.7 & 16.7 & 47.4 & 42.2 & 5.2 \\
5 & 1.53 & 2.82 & 37.6 & 2.22 & 41.1 & 43.3 & 24.4 & 18.9 \\
6 & 1.06 & 28.8 & 24.3 & 22.6 & 26.6 & 49.2 & 43.9 & 5.3 \\
7 & 1.10 & 38.0 & 18.4 & 29.9 & 20.1 & 50.0 & 42.1 & 7.9 \\
8 & 1.03 & 51.3 & 3.22 & 40.3 & 3.53 & 43.8 & 43.4 & 0.4 \\
9 & 1.01 & 33.2 & 18.2 & 26.1 & 19.8 & 45.9 & 45.5 & 0.4 \\
10 & 1.10 & 53.1 & 1.28 & 41.7 & 1.40 & 43.1 & 42.8 & 0.3 \\
\hline
\end{tabular}

1) Same as in Table 1.

2) Calculated $\mathrm{CO}_{2}$ values for ideal calcite and magnesite (see text p. 121).

3) $\mathrm{CO}_{2}$ def $=$ carbon dioxide deficiency (see text p. 121) 
raction determinations, the bulk of the brownish black weathering residue consisted of »limonitic» material i.e. hyrous oxides of iron and manganese, serpentine and of varying amounts of other silicates present in the original limestone as accessory minerals (cf. insoluble fraction of anal. nos. $1-3$ and 5 in Table 1). The rather fresh core (anal. No. 7) of a partly weathered limestone consisted of calcite, dolomite and minor accessory silicates including some serpentine (determined microscopically). The transition zone between the black crust and the core of the same sample contained dolomite and serpentine but no calcite (anal. No. 6) This is completely in accordance with the sollubility of the carbonates, calcite being more easily dissolved than dolomite (Krauskopf 1967, p. 109).

The chemical analyses of the samples are plotted in Table 1 . In addition to the weathered samles, fresh limestone, chipped from large practically unweathered boulders (the weathered material has been washed away by rain, e.g. Fig. 4C) found on the bottom of the gravel pit at site No. 2, was analyzed for the sake of reference (anal. Nos. 8-10, in Table 1).

To facilitate the comparison of the results, the assay data in Table 1 were multiplied by factor $\mathrm{K}=\frac{\Sigma}{\Sigma-\mathrm{HCl}}$. The product gives the respective concentrations on a »silicate-free» basis (= residue insoluble in hydrochloric acid). The recalculated values have been plotted in Table 2.

Pure calcium carbonate contains 56 percent $\mathrm{CaO}$ and 44 percent $\mathrm{CO}_{2}$; pure magnesium carbonate contains 47.8 percent $\mathrm{MgO}$ and 52.2 percent $\mathrm{CO}_{2}$. These percentages have been used to calculate the ideal concentration of the $\mathrm{CO}_{2}$ of the sample as though all the calcium and magnesium of the sample existed as their pure carbonates. The results are plotted in Table 2 and denoted $\mathrm{CO}_{2}\left(\mathrm{CaCO}_{3}\right)$ and $\mathrm{CO}_{2}\left(\mathrm{MgCO}_{3}\right)$ respectively. Since the loss on ignition can be used as an estimate of the $\mathrm{CO}_{2}$ concentration in the analyzed samples, the difference between the cal-
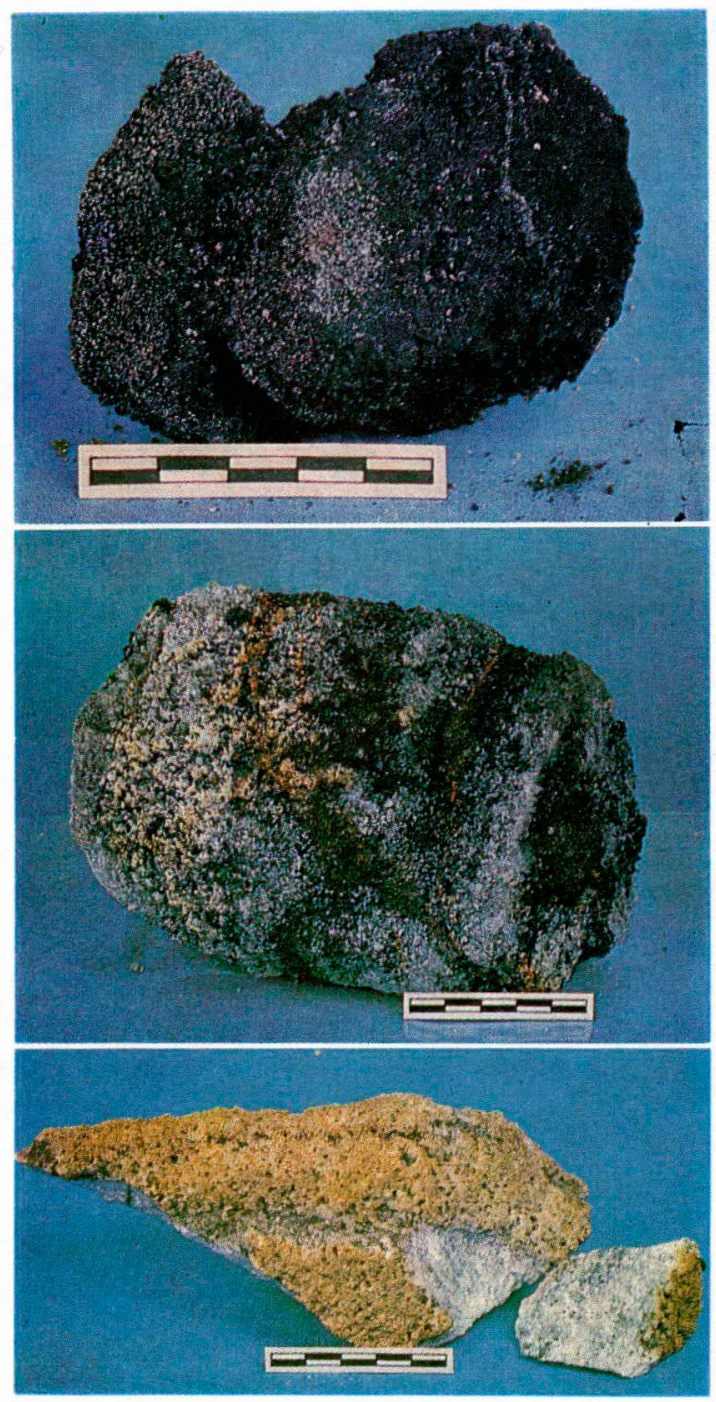

Fig. 4. Specimens from site No. 2 showing different stages of limestone weathering. A. completely weathered limestone, B. partly weathered limestone and C. fresh limestone with only a slightly corroded crust. Length of the scale is $5 \mathrm{~cm}$.

culated and the analyzed carbon dioxide contents, denoted $\mathrm{CO}_{2}$-deficiency in Table 2 , seems to indicate the state of weathering of the limestones (Fig. 5 and text p. 123).

The soil surrounding some of the weathered limestone erratics was sampled for chemical analysis. Total iron, manganese and carbon dioxide were determined from the $\mathrm{HCl}$ soluble 


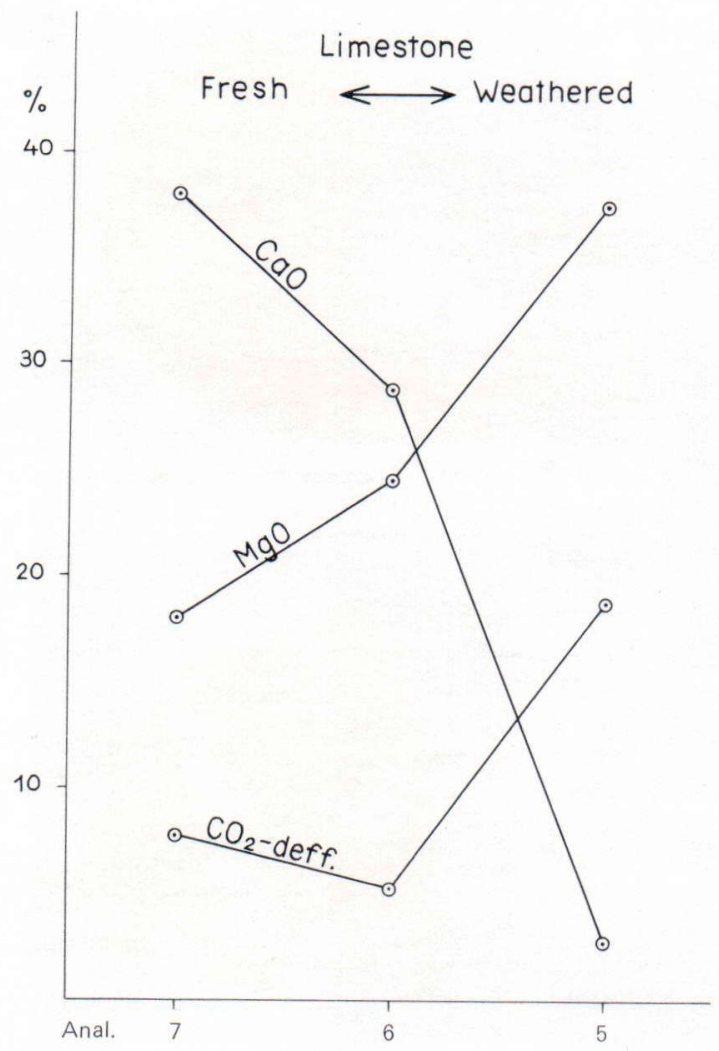

Fig. 5. Graph representing the calcium and magnesium concentrations and the $\mathrm{CO}_{2}$-deficiency of limestone at different stages of weathering (Table 1, anal. nos. 5-7).

fraction of the material. The results are plotted in Table 1. The assay data of two clossely spaced samples taken from a distance of $1 \mathrm{~cm}$ (anal. No. 11) and $5 \mathrm{~cm}$ (anal. No. 12) from the surface of a weathered limestone may suggest a diffusion of iron towards the limestone. The rest of the samples (anal. Nos. 13-16) show practically no variations in the iron and mangenese concentrations. These samples were taken at distances of 0.5-1.5 meters from a black lump (Fig. 3).

\section{Weathering of limestone}

The dissolving effect of groundwater on limestone is a common phenomenon. The active agent is generally considered to be the carbon dioxide dissolved in the water and to a large extent derived from the atmosphere. The decomposition of organic matter present in the soil may cause a considerable increase in the $\mathrm{CO}_{2}$ concentration in the water (Swinnerton, 1942). This dissolving effect was also treated by Eskola (1913) in a study dealing with the solution of crystalline limestone outcrops in southwestern Finland. He found that the thickest weathering crusts exist in limestones covered by soils permeable to groundwater. According to Eskola, weathering of a thickness of $10-15 \mathrm{~cm}$ is quite common, although deeper weathering occurs in limestone outcrops that have been covered by soil exhibiting a strong podsol profile. Thus in our case the disintegration of limestone erratics in glaciogenic material can be fully attributed to percolating groundwaters.

Before going into the details of the results of the present study, it is worthwhile noting that the solubility of magnesite $\left(\mathrm{MgCO}_{3}\right)$ is far greater than that of calcite $\left(\mathrm{CaCO}_{3}\right)$ which in turn is more soluble than dolomite, the double carbonate of calcium and magnesium $\left(\mathrm{CaMg}\left(\mathrm{CO}_{3}\right)_{2}\right)$. In limestone consisting of both last mentioned carbonates the calcite is dissolved considerably faster than the dolomite (e.g. Krauskopf, 1967).

In our particular case the assay data in Table 2 show that both calcitic and dolomitic erratics have likewise been attacked by percolating solutions. However, in the actual processes of weathering the calcium and magnesium components of dolomite act quite differently. This is exemplified by the graph in Fig. 5 based on assay data from Table 2.

With progressive weathering the calcium eancentration decreases while the relative concentration of magnesium increases. In other words, in the present case of weathering, mainly calcium is removed in solution. Another notew orthy observation is that a rapid increase in the $\mathrm{CO}_{2}$-deficiency occurs at a rather late stage of the weathering. It probably coincides with the solution of the final remains of calcitic material and the commencement of an accelerated weathering of the dolomitic fraction of the original limestone. 
The following is an attempt to explain the processes involved in the present problem of limestone decomposition. The unaltered limestone erratics in glaciogenic material are attacked by percolating groundwaters low in $\mathrm{pH}$ (averaging 6-6.5 in the study area) due to dissolved carbonic and possibly other organic and inorganic acids liberated from the upper horizon of the podsol profile. The first mineral to be dissolved is calcite. The bicarbonate and calcium ions thus formed are removed by the groundwater. As a result, the limestone loses weight causing a relative increase in the magnesium concentration. The dolomite is probably mainly attacked after the calcite has been dissolved. According to Krauskopf (op. cit.), the solution of dolomite is congruent, i.e. the follow ing reaction takes place:

$$
\mathrm{CaMg}\left(\mathrm{CO}_{3}\right)_{2} \longrightarrow \mathrm{Ca}^{++}+\mathrm{Mg}^{++}+2 \mathrm{CO}_{3}^{-} .
$$

The rather striking fact is that although calcium is removed in solution magnesium is immediately re-precipitated.

Hydromagnesite $\mathrm{Mg}_{4}(\mathrm{OH})_{2}\left(\mathrm{CO}_{3}\right)_{3} \cdot 3 \mathrm{H}_{2} \mathrm{O}$ is a common precipitate of magnesium in nature when enough $\mathrm{CO}_{3}^{-}$(i.e. dissolved carbon dioxide) is available (Krauskopf, op.cit.). A comparison of the loss on ignition values with the $\mathrm{MgO}$-values in Table 2 clearly shows that, at most, only part of the magnesium could be present as hydromagnesite. However, no hydromagnesite was detected by $\mathrm{X}$-ray diffraction. This could be due to poor crystallization. The fact that serpentine was a major constituent especially in the weathered limestone mentioned previously on page 120 (cf. anal. no. 4) suggests oddly enough a reaction between $\mathrm{Mg}^{++}$and silica, dissolved in the percolating solutions, to form $\mathrm{Mg}_{3} \mathrm{Si}_{2} \mathrm{O}_{5}(\mathrm{OH})_{4}$ (serpentine). It is however outside the scope of the present paper to determine the validity of such a reaction, especially since the available literature contained no records of serpentine formation at the low temperature and pressure conditions prevailing in the glaciogenic deposits.
The black substance (Figs. 1 and 3) denoting the location and shape of the former limestone erratics consists, as stated above, of hydrous oxides of iron and manganese. These were precipitated from the percolating solutions due to changes in the physicochemical conditions of the water induced by the decomposing limestone. Groundwater from the vicinity of site No 2 contained at an average $0.2 \mathrm{mg} \mathrm{Fe} / 1$ and $0.1 \mathrm{mg}$ $\mathrm{Mn} / \mathrm{l}$. The soil samples from site No 2 contained approximately $1.4 \% \mathrm{Fe}_{2} \mathrm{O}_{3}$ and $0.2 \% \mathrm{MnO}$ in $\mathrm{HCl}$-soluble form. In both cases, the iron and manganese have been leached out from the upper soil layers. At lower levels these may be precipitated either as a result of oxidation or e.g. due to a change in the $\mathrm{pH}$ of the solution in contact with carbonates as is the case with the brownish black earthy lumps. The actual processes leading to the concentration of iron and manganese in the voids of corroded limestone, also recorded by Eskola (1913), must be left to future studies to solve.

\section{Conclusions}

The present study shows that any limestone erratics embedded in e.g. glaciogenic deposits will be attacked by percolating solutions. The degree of weathering is probably mainly dependant on the chemistry of the groundwater and on the permeability of the soil. In the Lohja-region all the observed limestones less than a decimeter in diameter have been completely distroyed and replaced by a brownish black earthy material consisting of various secondary minerals of iron, mangenese and magnesium, etc. The above explains why a geologist making stone counts in drift rarely recognizes limestones even in areas where these are common constituents of the Precambrian bedrock. In other words, limestone erratics need not be absent, but it seems more probable that he has failed to identify dark earthy lumps as the remains of once fresh limestones. 
Acknowledgements: The authors are grateful to Messrs. Kai Hytönen, Ph. D. and Pekka Kallio, Mag. Phil. for the X-ray determinations of the weathered limestone samples. To Mr. Risto Saikkonen, Mag. Phil. we want to express our sincere thanks for the many chemical determinations required by the present study.

\section{ADDENDUM}

The weathering of Cambrian stinkstone boulders in till from Jämtland, Sweden has been related in a recent paper by Jan Lundqvist, Ann Marie Byström-Asklund and Britt Marie Eriksson (1967. Weathering of a stinkstone from Fåker, Jämtland, Sweden. GFF vol. 89 pp. 432
-439). Their investigations indicate that percolating solutions containing humus have removed calcite but deposited e.g. manganese. They consider the weathering a postglacial phenomenon, which is in agreemet with the results of the present study.

\section{REFERENCES}

Eskola, P. (1913) On phenomena of solution in Finnish limestones and on sandstone filling cavities. Bull. Comm. géol. Finlande No. 36, pp. 50.

Eskola, P., V. Hackman, A. LaItAkari \& W. W. WilkMAN (1919) Suomen kalkkikivi. Summary: Limestones in Finland. Geotekn. tied. No. 21, pp. . 265.

HÄrme, M. (1960) Kivilajikartan selitys. Explanation to the map of rocks. Lehti-Sheet B 1. Turku. Suomen geologinen yleiskartta 1: 400000 . Geologinen tutkimuslaitos.

Нyчррё, E. (1963) On the late-Quaternary history of the Baltic Sea. Fennia 89, No. 1, pp. 188-194.

Krauskopf, Konrad B. (1967) Introduction to Geochemistry. International Series in the Earth and Planetary Sciences. McGraw-Hill, New York, pp. 721.

Laitala, M. (1961) Kallioperäkartan selitys. Explanation to the map of rocks. Lehti - Sheet 2032. Siuntio.
Suomen geologinen kartta 1:100 000. Geologinen tutkimuslaitos.

Parras, K. (1954) Prospektering och geologiska undersökningar i Lojo-området. Vuoriteollisuus - Bergshanteringen No. 2.

Parras, K. and M. Tavela (1954) The limestone deposits in Lohja. Geotekn. julk. No. 55, pp. 69-74.

Sauramo, M. (1923) Studies on the Quaternary varve sediments in Southern Finland. Bull. Comm. géol. Finlande No. 60, pp. 164.

Simonen, A. (1960) Pre-Quaternary rocks in Finland. Bull. Comm. géol. Finlande No. 191, pp. 49.

Swinnerton, A. C. (1942) Hydrology of Limestone Terranes. pp. 656-677 in Physics of the Earth IX, Hydrology, ed. O. E. Meinzer McGraw-Hill, New York, 712, pp. (Dover edition).

Manuscript received, March 1, 1968. 